\title{
Interleukin-6 Levels in the Cervicovaginal Fluid of Pregnant Women and Its Predictive Value in Preterm Delivery
}

\author{
Hamile Kadınlarda Servikovajinal Sıvıda İnterlökin-6 Düzeyleri ve \\ Preterm Eylem Prediktivitesi
}

\section{(D) Pelin Ergenekon}

Medipol University Sefaköy Hospital, Clinic of Obstetrics and Gynecology, İstanbul, Turkey

\section{Abstract}

Objective: The aim of this study was to determine interleukin (IL)6 levels in the cervicovaginal fluid of pregnant women and its value in predicting preterm delivery.

Method: One hundred and eleven pregnant women were retrospectively included in the study. Cervicovaginal secretions for each pregnant woman were obtained with a sterile Dacron swab for IL-6 detection. IL-6 was determined using an enzyme-linked immunosorbent assay method.

Results: The mean IL-6 levels were found to be significantly higher in the preterm delivery group $(5.84 \pm 2.09 \mathrm{pg} / \mathrm{mL})$ than in the term delivery group $(2.24 \pm 0.77 \mathrm{pg} / \mathrm{mL})(p=0.001)$. Relationships were found between IL-6 levels and the frequency of intra-amniotic infection, preterm birth and the history of previous preterm birth.

Conclusion: A strong association was found between increased cervicovaginal fluid IL-6 levels and preterm delivery. Results suggest that measurement of IL-6 levels from cervicovaginal swab samples during pregnancy can be used to identify patients with risk as a predictive biomarker for preterm birth.

Keywords: Cytokines, IL-6, premature birth

\section{Öz}

\begin{abstract}
Amaç: Bu çalışmanın amacı hamile kadınların servikovajinal sıvı örneklerinde interlökin (IL)-6 düzeylerini analiz etmek ve preterm doğum için prediktif rolünü belirlemektir.
\end{abstract}

Yöntem: Çalışmaya 111 gebe kadın retrospektif olarak dahil edildi. Her kadın için servikovajinal sekresyonlar, IL-6 saptaması için steril bir Dacron sürüntüsü ile elde edildi. IL-6, enzime bağlı immünosorbent test yöntemi kullanılarak belirlendi.

Bulgular: Ortalama servikovajinal SIVI IL-6 düzeyleri erken doğum grubunda $(5,84 \pm 2,09 \mathrm{pg} / \mathrm{mL})$ term dönem doğum grubuna göre $(2,24 \pm 0,77 \mathrm{pg} / \mathrm{mL})$ anlamlı olarak daha yüksek bulundu $(p=0,001)$. IL-6 ile intra-amniyotik enfeksiyon, preterm doğum ve önceki preterm doğum öyküsü arasında pozitif ilişki saptandı.

Sonuç: Artmış servikovajinal sıvı IL-6 düzeyleri ile erken doğum arasında güçlü bir ilişki bulunmuştur. Hamilelik döneminde servikovajinal sıv IL-6 seviyesinin ölçümü, yüksek riskli kadınların erken doğum eyleminin saptanması için bir öngörücü biyobelirteç olarak kullanılabilir.

Anahtar kelimeler: Erken doğum, IL-6, sitokinler

\section{Introduction}

Preterm birth is described as delivery before the $37^{\text {th }}$ week of gestation and is associated with significantly elevated perinatal morbidity and mortality. It is a heterogeneous condition with multi-factorial etiology, including demographic factors, placental ischemia, decidual hemorrhage, placental abruption, trauma, stress, environmental factors, genital tract infections and chronic conditions such as blood clotting disorders, gestational diabetes, and hypertension (1). Preterm birth has a profound effect on health systems due to the short and long-term

Address for Correspondence: Pelin Ergenekon, Medipol University Sefaköy Hospital, Clinic of Obstetrics and Gynecology, İstanbul, Turkey E-mail: pelin.ergenekon@gmail.com ORCID: orcid.org/0000-0002-8676-8314 Received: 29.04.2020 Accepted: 23.08.2020

Cite this article as: Ergenekon P. Interleukin-6 Levels in the Cervicovaginal Fluid of Pregnant Women and Its Predictive Value in Preterm Delivery. Bagcilar Med Bull 2020;5(3):138-143

${ }^{\oplus}$ Copyright 2020 by the Health Sciences University Turkey, Bagcilar Training and Research Hospital Bagcilar Medical Bulletin published by Galenos Publishing House. 
disabilities related to the condition. It creates high economic and social costs to families and health care systems, and is further associated with conditions including cerebral palsy, necrotizing enterocolitis, retinopathy of prematurity, bronchopulmonary dysplasia, and Respiratory Distress syndrome (2). Beck et al. (3) found that $28 \%$ of all neonatal deaths in the first week of life were seen after preterm birth. Considering that the estimated global frequency of preterm birth is $9.6 \%, 10$ to 13 million babies are born with preterm delivery in one year and face the inherent risks of this condition (3). Early detection of preterm labor is important, but it is considered to be very difficult since its initial symptoms are usually mild and further symptoms often appear too late. Since the underlying etiology of preterm labor still remains uncertain, maternal biomarkers predicting preterm labor are still being widely investigated.

It has been previously suggested that the inflammatory pathway plays an important role in the etiopathogenesis of preterm delivery (4). IL-6 is a multifunctional cytokine and is widely expressed in the female reproductive tract and gestational tissues. It is involved in inflammation and has a central role in the host defense mechanism through the stimulation of immunoglobulin production, activation of T-cell proliferation, and differentiation of myeloid cells. The production of prostaglandins can be induced by IL-6, causing uterine contractions and cervical ripening. Several studies in the literature have found altered levels of IL-6 in relation to preterm delivery, but their results remain inconsistent (5). This study aimed to determine IL-6 levels in the cervicovaginal fluid of pregnant women and to identify its predictive value for preterm delivery.

\section{Materials and Methods}

\section{Study Design}

This retrospective study was carried out from November 2017 to June 2018 in Istanbul, Turkey. A total of 111 pregnant women with singleton gestation were recruited from a private gynecological practice. The study included 45 patients with term delivery and 66 patients who had preterm labor. Gestational age was assessed according to the last menstruation date and first trimester obstetric radiologic examination. Preterm delivery was defined as birth before the $37^{\text {th }}$ week of gestation. Participants with hypertensive disorders in pregnancy, obstetrical hemorrhage, vaginal bleeding, cervical cerclage, fetal anomalies, multiple pregnancy, fetal growth restriction, premature rupture of the membrane, and malignancies were excluded from the study. A total of 22 patients were excluded according to the exclusion criteria. Obstetric data and clinical results of patients, including maternal age, maternal education status, the presence of intra-amniotic infection, marital status, the history of previous preterm birth and birth weeks of infants were obtained from patients' medical files. Intra amniotic infection was diagnosed via the presence of 2 or more of the following criteria: temperature $\geq 38^{\circ} \mathrm{C}$, maternal or fetal tachycardia, uterine tenderness, elevated peripheral white blood cell count, and purulent amniotic fluid.

\section{Ethical Issues}

Ethics committee approval was obtained from the noninterventional Clinical Research Ethics Committee of İstanbul Medipol University (decision number: 519, decision date: 25/06/2020). All research procedures were conducted in agreement with the ethical standards specified in the Declaration of Helsinki. Written and verbal informed consent was obtained from participating women prior to sampling and their participation in this study.

\section{Detection of Interleukin-6}

Cervicovaginal secretion samples were obtained and collected from each pregnant woman included in the study for 3 to 8 weeks gestation at the time of initial admission for further analysis. Samples were frozen at $-40{ }^{\circ} \mathrm{C}$ up to 12 months until IL- 6 testing. After collecting all patients' cervicovaginal samples, they were analyzed together after delivery. To obtain cervicovaginal fluid, a sterile Dacron swab was placed into the posterior fornix following positioning of a sterile speculum, and gently rotated for 15 seconds to ensure complete absorption of cervicovaginal secretion. The swab was transferred into to a test tube containing phosphate-buffered saline and stored at $-40^{\circ} \mathrm{C}$. Before biochemical analyses, the sample was thawed and centrifuged at $4{ }^{\circ} \mathrm{C}$ and 5.000 RPM for 10 minutes. The supernatant was used for the measurement of IL-6 levels via an ELISA kit (Elabscience Biotechnology, USA) as per the manufacturer's instructions. The color intensities were determined using an ELx 800 microplate absorbance plate reader (BioTek, USA) with a $450 \mathrm{~nm}$ filter. The results were expressed in picograms per milliliter (pg/mL).

\section{Statistical Analysis}

The SPSS version 22.0 soft $\neg$ ware (Chicago, IL, USA) was used to perform all statistical analyses. The Shapiro-Wilk test was used to assess the normality of distribution. Data were expressed as mean \pm standard deviation or frequency (percentage). Comparison of the groups was performed using the Mann-Whitney U test. The Spearman's correlation 
test was used to evaluate correlations. $\mathrm{P}<0.05$ values were accepted as statistically significant results.

\section{Results}

A total of 111 pregnant women with singleton gestation were involved in the study. The mean age was $31.65 \pm 4.87$ years for patients with preterm delivery and 31.24 \pm 4.67 years for women with term delivery $(p=0.926)$. Nine patients with preterm delivery had intra-amniotic infection, while one patient presented intra-amniotic infection in the term group $(\mathrm{p}=0.039)$.

No significant differences were found between the groups in terms of age and history of previous preterm birth (all, $\mathrm{p}>0.05)$. Age, education status, history of previous preterm birth, and intra-amniotic infection status were shown in Table 1.

The mean IL-6 levels were $5.84 \pm 2.09 \mathrm{pg} / \mathrm{mL}$ in women with preterm delivery and $2.24 \pm 0.77 \mathrm{pg} / \mathrm{mL}$ in those with term delivery. The boxplot distribution graph of IL-6 levels was shown in Figure 1. IL-6 levels were found to be significantly higher in the preterm delivery group $(\mathrm{p}=0.001)$ (Figure 2).

Correlation analyses between patients' characteristics and IL-6 levels were shown in Table 2. Positive relationships were found between IL-6 levels and the absence of intra-amniotic infection, preterm birth and the history of previous preterm birth. We also showed a negative correlation between IL-6 and birth week. Furthermore, intra-amniotic infection was also found to be associated with preterm delivery (Table 2 ).

\section{Discussion}

The current study aimed to investigate cervicovaginal levels of IL- 6 and to determine predictive value of cervicovaginal fluid IL-6 levels for preterm delivery. We demonstrated increased IL-6 levels in the cervicovaginal samples of women

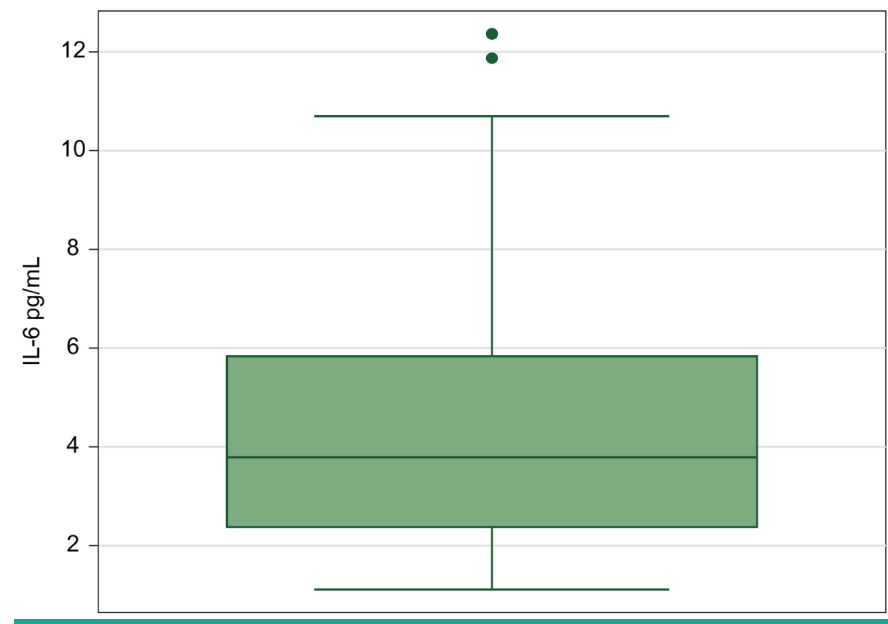

Figure 1. Box plot, distribution of IL-6

IL-6: Interleukin-6

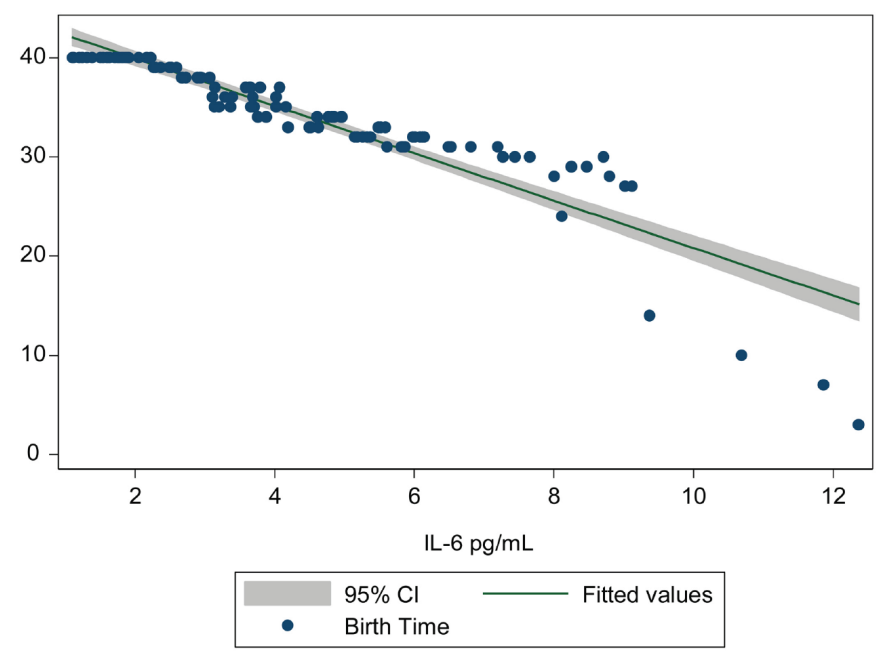

Figure 2. OLS scatterplot, relationship between IL-6 levels and birth time

IL-6: Interleukin-6, CI: Confidence interval

Table 1. Demographic data of participants

\begin{tabular}{|c|c|c|c|c|}
\hline & $\begin{array}{l}\text { Total } \\
(n=111)\end{array}$ & $\begin{array}{l}\text { Women with term delivery } \\
(n=45)\end{array}$ & $\begin{array}{l}\text { Women with preterm } \\
\text { delivery }(n=66)\end{array}$ & $\mathbf{p}$ \\
\hline Age & $31.49 \pm 4.77$ & $31.24 \pm 4.67$ & $31.65 \pm 4.87$ & 0.926 \\
\hline \multicolumn{5}{|l|}{ Education status } \\
\hline University & $60(54.1 \%)$ & $23(51.1 \%)$ & $37(56.1 \%)$ & \\
\hline High school & $27(24.3 \%)$ & $12(26.6 \%)$ & $15(22.7 \%)$ & 0.158 \\
\hline Post-graduate & $24(21.6 \%)$ & $10(22.2 \%)$ & $14(21.2 \%)$ & \\
\hline The history of previous preterm birth & $24(21.6 \%)$ & $8(17.7 \%)$ & $16(24.2 \%)$ & 0.417 \\
\hline IL-6 & $4.38 \pm 2.45$ & $2.24 \pm 0.77$ & $5.84 \pm 2.09$ & 0.001 \\
\hline
\end{tabular}

IL-6: Interleukin-6. n: Number

Data are presented as mean (standard deviation) or frequency (percentage) 
Table 2. Relationship between patients' characteristics and IL-6 levels

\begin{tabular}{|c|c|c|c|c|c|c|c|c|}
\hline & & INF & EDU & Age & BW & PB & PPB & IL-6 \\
\hline \multirow{2}{*}{ Intra-amniotic infection } & $r$ & 1 & 0.087 & 0.054 & -0.339 & $0.196 *$ & -0.012 & $0.316 * *$ \\
\hline & $\mathrm{p}$ & - & 0.361 & 0.574 & 0.001 & 0.040 & 0.897 & 0.001 \\
\hline Education status & $\mathrm{p}$ & 0.361 & - & 0.357 & 0.712 & 0.706 & 0.531 & 0.821 \\
\hline Age & r & 0.054 & 0.088 & 1 & -0.136 & 0.042 & 0.186 & 0.079 \\
\hline Birth week & $\mathrm{p}$ & 0.001 & 0.712 & 0.155 & - & 0.001 & 0.012 & 0.001 \\
\hline \multirow{2}{*}{ The presence of PB } & $r$ & $0.196 *$ & -0.036 & 0.042 & $-0.637 * *$ & 1 & 0.077 & $0.726 * *$ \\
\hline & $\mathrm{p}$ & 0.040 & 0.706 & 0.661 & 0.001 & - & 0.421 & 0.001 \\
\hline Previous PB & r & -0.012 & -0.060 & 0.186 & $-0.237^{*}$ & 0.077 & 1 & $0.311^{* *}$ \\
\hline
\end{tabular}

INF: The absence of intra-amniotic infection, EDU: Education status, BW: Birth week, PB: Preterm birth, PPB: Previous preterm birth, IL-6: Interleukin-6

who experienced preterm birth. This result suggests that the evaluation of cervicovaginal IL-6 may have predictive value for preterm delivery and could be important in the management of women at risk for preterm delivery.

Preterm birth is described as the occurrence of birth before 37 weeks of gestation and is one of the major causes of perinatal mortality and morbidity worldwide. Antenatal prediction of preterm birth would be critical in determining women at high risk and in reducing the burden of morbidities related to this condition, yet assessment remains uncertain and difficult. Many maternal or fetal characteristics associated with the occurrence of preterm labor have been identified, such as maternal age, history of preterm birth, ethnicity, low socioeconomic status, low education, pregnancy weight, psychosocial stress, drug and alcohol abuse, environmental factors and intrauterine infection $(2,4,5)$. In accordance with the literature, we demonstrated that ten mothers had intra-amniotic infection in our study group and 9 of them resulted in preterm labor. In addition, 24 of our patients had a previous history of preterm pregnancy and 7 of them resulted with preterm delivery. We also found positive association between intra-amniotic infection and preterm labor. Our results indicate that intrauterine infection and previous preterm birth history are important characteristics for preterm labor. These patients should be considered as high-risk for preterm labor and should be monitored closely.

Researchers have reported biological pathways associated with preterm delivery, including inflammation, extracellular matrix degradation, fetal infection, fetal stress, fetal anomalies and abnormal estrogen metabolism (4). IL-6 is a pleiotropic pro-inflammatory cytokine and has been investigated in numerous gynecological diseases including unexplained infertility, recurrent miscarriage, preeclampsia, and preterm labor (6). The expression of IL-6 is altered with infection, inflammation and stress caused by stimuli with various factors, such as tumor necrosis factor-alpha, IL-1 and lipopolysaccharide (7). The expression of IL- 6 has been found to be low in the early and mid-trimester, but increased in the presence of uterine infection (8). Intra-amniotic infection increases the production of cytokines and triggers the synthesis and release of prostaglandins that are responsible for cervical ripening and uterine contraction; thus, infections may result in preterm labor through this mechanism (7). Genetic studies have shown relationships between a single nucleotide polymorphism in the promoter region of the IL- 6 gene and elevated risk of preterm delivery (9). Several studies in the literature have found altered levels of IL-6 in various biological fluids (serum, amniotic fluid and cervicovaginal fluid) in relation with preterm delivery. Romero et al. (8) showed higher IL-6 levels in the amniotic fluid of mothers who had preterm delivery with intra-amniotic infection compared to those without infection, suggesting that amniotic fluid IL-6 may have diagnostic and prognostic value for preterm labor. Jung et al. (10) revealed that higher levels of cervicovaginal IL-6 were related to delivery within 7 days among women with preterm labor. Lockwood et al. (11) demonstrated 4.2-fold increased cervical IL-6 concentrations among 
patients with preterm labor compared to those that had term labor. In a study conducted by Reyna-Vallasmil and colleagues, cervicovaginal IL-6 levels were measured in the second trimester and preterm labor developed in women with higher IL-6 levels (12). LaShay et al. (13) showed increased cervicovaginal IL-6 in 135 women with the symptoms of suspected preterm delivery. Lange and coworkers revealed an elevation of cervical IL-6 levels in 31 patients with preterm delivery, who had intact membranes (14). Perales-Puchalt et al. (15) demonstrated in a study involving 100 mothers with a threat of preterm labor that five women who delivered within two days and six women who delivered within 7 days had high cervical IL-6. They also found a high negative predictive value of cervical IL-6 levels for the prediction of preterm birth. Woodworth et al. (16) showed in 660 cervicovaginal fluid samples that the positive and negative predictive values for cervicovaginal IL- 6 were $16 \%$ and $97 \%$. Furthermore, they reported that IL-6 levels were strongly associated with the occurrence of delivery within 14 days of collection (16). In agreement with these studies, we found higher cervicovaginal IL-6 levels in women who had preterm labor. We also found correlations between IL- 6 and the absence of intra-amniotic infection and also duration of pregnancy. Our study supports current evidence that IL-6 is involved in parturition and is an effective predictor of preterm delivery. IL-6 may be involved in the etiology and pathogenesis of preterm delivery through its stimulation of prostaglandin synthesis. IL-6 may release into the cervicovaginal fluid during the breakdown of chorio-decidual adhesion or as a direct response to increased inflammation. Our study also demonstrates that circulating cytokines may have a role in the pathophysiology of preterm delivery. Our results indicate that cervical IL-6 levels can be utilized as a cheap, direct and practical method to predict preterm labor, and could be an alternative to amniotic fluid testing.

There were several limitations in this study. The most important was the fact that we performed only a single cervicovaginal IL-6 measurement. Besides, the sample size of study can be considered small; however, we excluded patients that could have confounding factors. Larger studies are necessary to confirm our findings.

\section{Conclusion}

This retrospective study demonstrates that cervicovaginal fluid IL-6 levels were altered in women with preterm birth. There is a strong association between increased cervicovaginal fluid IL-6 levels and prediction of preterm delivery. Measurement of cervicovaginal IL-6 levels during pregnancy may be used as a predictive biomarker for the detection of preterm birth and women at high-risk; thereby providing early interventions and intensive antenatal care opportunity to reduce perinatal morbidity and mortality.

\section{Ethics}

Ethics Committee Approval: Ethics committee approval was obtained from the non-interventional Clinical Research Ethics Committee of İstanbul Medipol University (decision number: 519, decision date: 25/06/2020).

Informed Consent: Written and verbal informed consent was obtained from participating women prior to sampling and their participation in this study.

Peer-review: Externally peer-reviewed.

Financial Disclosure: The author declared that this study received no financial support.

\section{References}

1. Mierzynski R, Dluski D, Nowakowski L, Poniedzialek-Czajkowska E, Leszczynska-Gorzelak B. Adiponectin and Omentin Levels as Predictive Biomarkers of Preterm Birth in Patients with Gestational Diabetes Mellitus. Biomed Res Int 2018;2018:7154216.

2. Lucaroni F, Morciano L, Rizzo G, D’Antonio F, Buonuomo E, Palombi L, et al. Biomarkers for predicting spontaneous preterm birth: an umbrella systematic review. J Matern Fetal Neonatal Med 2018;31(6):726-734.

3. Beck S, Wojdyla D, Say L, Betran AP, Merialdi M, Requejo JH, et al. The worldwide incidence of preterm birth: a systematic review of maternal mortality and morbidity. Bull World Health Organ 2010;88(1):31-38.

4. Chan RL. Biochemical markers of spontaneous preterm birth in asymptomatic women. Biomed Res Int 2014;2014:164081.

5. Oskovi Kaplan ZA, Ozgu-Erdinc AS. Prediction of Preterm Birth: Maternal Characteristics, Ultrasound Markers, and Biomarkers: An Updated Overview. J Pregnancy 2018;2018:8367571.

6. Prins JR, Gomez-Lopez N, Robertson SA. Interleukin-6 in pregnancy and gestational disorders. J Reprod Immunol 2012;95(1-2):1-14.

7. Devi YS, DeVine M, DeKuiper J, Ferguson S, Fazleabas AT. Inhibition of IL-6 signaling pathway by curcumin in uterine decidual cells. PLoS One 2015;10(5):e0125627.

8. Romero R, Avila C, Santhanam U, Sehgal PB. Amniotic fluid interleukin 6 in preterm labor. Association with infection. J Clin Invest 1990;85(5):1392-1400,

9. Simhan HN, Krohn MA, Roberts JM, Zeevi A, Caritis SN Interleukin-6 promoter -174 polymorphism and spontaneous preterm birth. Am J Obstet Gynecol 2003;189(4):915-918.

10. Jung EY, Park JW, Ryu A, Lee SY, Cho SH, Park KH. Prediction of impending preterm delivery based on sonographic cervical length and different cytokine levels in cervicovaginal fluid in preterm labor. J Obstet Gynaecol Res 2016;42(2):158-165. 
11. Lockwood CJ, Ghidini A, Wein R, Lapinski R, Casal D, Berkowitz RL. Increased interleukin-6 concentrations in cervical secretions are associated with preterm delivery. Am J Obstet Gynecol 1994;171(4):1097-1102.

12. Reyna-Villasmil E, Mejia-Montilla J, Reyna-Villasmil N, TorresCepeda D, Santos-Bolivar J, Fernandez-Ramirez A. Cervicovaginal interleukin- 6 in the prediction of preterm delivery. Rev peru ginecol obstet 2016;62(2):175-181.

13. LaShay N, Gilson G, Joffe G, Qualls C, Curet L. Will cervicovaginal interleukin-6 combined with fetal fibronectin testing improve the prediction of preterm delivery? J Matern Fetal Med 2000;9(6):336341.
14. Lange M, Chen FK, Wessel J, Buscher U, Dudenhausen JW. Elevation of interleukin 6 levels in cervical secretions as a predictor of preterm delivery. Acta Obstet Gynecol Scand 2003;82(4):326329.

15. Perales-Puchalt A, Brik M, Diago VJ, Perales A. The negative predictive value of cervical interleukin- 6 for the risk assessment of preterm birth. J Matern Fetal Neonatal Med 2013;26(13):12781281.

16. Woodworth A, Moore J, G'Sell C, Verdoes A, Snyder JA, Morris L, et al. Diagnostic accuracy of cervicovaginal interleukin-6 and interleukin-6: albumin ratio as markers of preterm delivery. Clin Chem 2007;53(8):1534-1540. 